Review of Chinese and Americans: A Shared History. Guo-qi Xu, Chinese and Americans: A Shared History, 332pp. Cambridge, Massachusetts and London: Harvard University Press, 2014.

\title{
HUANG Yi*
}

Keywords: China-U.S. relations, Sino-American Messengers, the Internationalization; Modern Cultural intercourse.

This monograph consists of three parts, covering the period from mid-1 $19^{\text {th }}$ century until the restoration of diplomatic relations between the PRC and the United States in the mid- $20^{\text {th }}$ century. The topics of the three parts are as follows.

Part One: Messengers of the Nineteenth Century

Part Two: The Internationalization of China and the United States

Part Three: Popular Culture and SinoAmerican Relations

The subject of the part one is messengers of the nineteenth century. It mainly describes

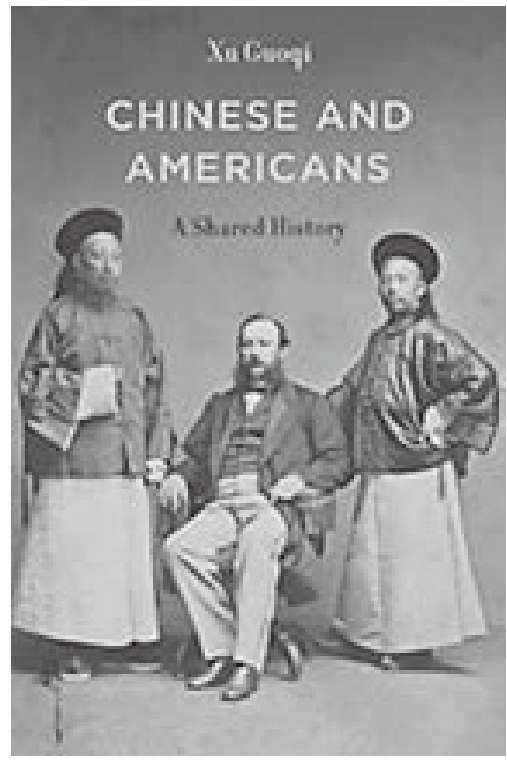
the early intercourse between Late Qing China and the United States, which began in the 1860s, through the following three historical events: the Anson Burlingame Embassy toward the western powers, the Chinese Education Mission in the nineteenth century America, and Ge Kunhua's, extraordinary experience as the first Chinese language teacher in the United States. The first part gives us a full sense of the progressive spirit of the Chinese people in the process of modernization and

* Huang Yi 黄逸 is MA Student, Graduate School of East Asian Cultures, Kansai University 
the broad mind of the American nation. Undoubtedly, after the disaster of the Boxer Uprising from 1900 to 1901 , China finally realized the necessity of keeping in line with the modern international community. Therefore, the early 20th century is an important moment in the Chinese history when ancient China began to internationalize.

In the part two, $\mathrm{Xu}$ uses a lot of first-hand materials to show the influence of American civilization on China in the early 20th century through the intercourse between two remarkable American scholars, Frank Johnson Goodnow and John Dewey, and China. As a messenger of American administrative law and constitutional adviser of Yuan Shi-kai administration, Goodnow asserted that the Chinese people at that time were not mature enough for a democratic form. This caused him a long misunderstanding. On the other hand, he conveyed the legal knowledge to China and kept the American government and elite organizations informed about the development of Chinese internationalization. The intercourse between Dewey and the Chinese younger intellectual generation in the early $20^{\text {th }}$ century shows another aspect of American culture's influence on China. Through the dissemination of his many Chinese students and admirers, Dewey's philosophy and ideas on education became popular in China for a while, and exerted a certain influence on the New Culture Movement and the New Life Movement in the modern Chinese history.

Part three begins with the YMCA and the Linkage of Modern Chinese Sports, especially the connection with China's Olympic dream. Then, through the sport intercourse of the young People's Republic toward the American people, so called the Ping-Pong diplomacy, explores the phenomenon of multicultural intercourse in modern U.S.-China relations. Throughout this work, $\mathrm{Xu}$ uses a great deal of historical documents and materials in Chinese and English, takes their shared history as breakthrough point of SinoAmerican relations in the past 200 years, highlights the shared characteristics of Sino-American historical studies through the narration of some important historical figures and historical events, and provides a new perspective and field for the future study of U.S.-China relations.

Among the three parts, undoubtedly, the views on Anson Burlingame and his mission in the first part gives me the greatest inspiration and influence. ${ }^{1}$ In this part, Anson Burlingame is regarded as the representative of American civilization. He successfully organized and implemented the cooperation policy of the United States towards Qing China, which provides a construc-

1 The subject of my dissertation is a comparative study of the Anson Burlingame and Iwakura Embassies from the perspective of Anglo-American news reports of the $19^{\text {th }}$ century. 
tive precedent for the open door policy at the end of the $19^{\text {th }}$ century. As the author points out, the success of Burlingame's cooperation policy depends first on the cooperation of Britain, the strongest country at that time, and the coordination with European powers. More importantly, after the bitter lessons of the first and second opium wars, the ancient Celestial Empire began to be willing to engage with Western nations in an equal manner, especially under the encouragement of the friendly Anson Burlingame to China, to seek a new mode of relations between China and western world. Inspired by this spirit of the times, Anson Burlingame, as the representative of the youngest nation towards the oldest nation of the world, and eventually led China's first modern diplomatic embassy to the wider world. In this moment, the value of the first Chinese messenger is observed by the American media:

One of the greatest honors ever paid to an American citizen, one of the greatest acknowledgments and compliments ever given abroad to this country, and one of the most useful positions ever awarded to one of our countrymen, is contained in the recent appointment of Hon. Anson Burlingame as Ambassador to all the treaty Powers by the Chinese government....This Honour is unique. Very few countries ever selected an ambassador before from among the citizens and officers of the country to be visited, and then extended his position to other countries and confided to him the gravest matters of international law and of commerce. The mission is highly important, too, since it is designed to advance our Pacific trade, and gives us full control of Chinese relations with Europe, one of the most important and delicate matters pertaining to our diplomacy. We feel a natural and national pride in the selection thus made by China for such important work, and cannot but believe that the mission will be signally valuable to our trade and manufactures, and useful to our growing relations with the Orient. ${ }^{2}$

Here, Burlingame is actually worthy of the China's first messenger, as $\mathrm{Xu}$ argues. At the same time, because of his special status, serving as both American ambassador to China and a full representative of the Chinese court to the West, he made a historic contribution to Sino-American relations. Therefore, it is self-evident that the real history of Anson Burlingame and his embassy is not only a part of Chinese history, but also a part of American history. It is also an important part of the history of the intercourse of modern Chinese and Western civilizations.

In this work, the shared history between China and the United States is woven by the personal experiences of those important messengers. In fact, the

2 North American and United States Gazette, Feb.10, 1868. 
Sino-American history which is shared by China and the United States is a glorious crown weaved by the tireless efforts of countless Chinese and American personages, who dedicated themselves to mutual understanding and cooperation between the nations of the United States and China for a long time. Although Anson Burlingame occupies an unshakable position in SinoAmerican relations, there were more Americans who stood behind him, and who were earlier than him, rooted in the traditional Chinese society, and devoted themselves to seeking the integration and coexistence of Chinese and Western cultures. For example, Samuel Wells Williams is mentioned many times in this work. ${ }^{3}$ If we may say, Burlingame, the modern Moses from the youngest nation of the world led Cathay into the modern international family by the way of politics and diplomacy, the influence of Samuel Wells Williams may be more profound and significant in the Sino-American relations. All of works of Samuel Wells Williams reveal an outstanding American sinologist's understanding, sympathy, and expectation of ancient China. This noble behavior also runs through Anson Burlingame's short and glorious life. ${ }^{4}$ In 1875, when Samuel Wells Williams retired and returned to the United States, the American media's comments on his service and career in China are as follows:

This service so impressed our Government that he was at once commissioned as Secretary of Legation to China, and he still holds that position, under the oldest Commission in our diplomatic corps. During twenty years of labor inadequately paid, he has been of more value to our country than any of our Ministers to China; and in the three treaties with that country, which bear the names of Cushing, Ward and Burlingame, respectively, Dr. Williams was the intelligent adviser and agent, and without his acquaintance with the country and the Governments and the people, probably our diplomacy would have been in vain. ${ }^{5}$

As first China's messenger, Burlingame laid a solid foundation for the development of Sino-American relations. That is, the United States treats China equally, sincerely helps her enter a modern civilized society and helps her realize modernization. The product of this consensus is the Burlingame Treaty signed in Washington in July 1868. This treaty opened the door to modern Sino-American exchanges. As described in this work, it provides a

$3 c f$. 陶徳民編『衛三畏在東亜: 美日所蔵資料選編』、大象出版社、2016年。陶徳民「近代 東アジアの変貌を目撃した二人の西洋人一『衛三畏文集』とDiaries and Travel Journals of Ernest Satowに寄せた序文一」『関西大学中国文学会紀要』(37) (2016年)。

4 cf. Frederick Wells Williams. Anson Burlingame and the First Chinese Mission to Foreign Powers. New York: Charles Scribner's Sons, 1912.

5 “A Remarkable Missionary Printer," Daily Evening Bulletin, Sept.13, 1875. 
precious opportunity for the younger generation of China to study in the United States and understand the values of the American nation. The following report shows the views of the American media in the 1870s on the earliest Chinese schoolboys studying in the United States.

The Chinese Government has sent forty students to the United States. Those young men, who are of the Mandarin class, are to receive a collegiate education in this country, in a course that shall embrace a knowledge of our language, and practical art and science. The intention at first was to send these students to England, but the advice and influence of George. F. Seward, United States Consul-General, caused them to be sent to our country. Each one of these young men will go back, unintentionally, but surely, as a preacher on the value of international intercourse, and the folly of the past exclusiveness of the greatest of Asiatic nations. ${ }^{6}$

It was from then on that the American nation began to really influence China, and China began to really face up to the young United States. On August 8, 2008, on the day of the opening ceremony of the Beijing Olympic Games, the newly established Embassy of the United Sates in the People's Republic held a ribbon cutting ceremony. To this ceremony, the US Department of State issued a memorial album entitled 《共同走过的日子-美中 交往两百年》A Journey Shared: The United States and China-Two Hundred Years of History. John Israel, a professor of Chinese history at the University of Virginia, pointed out in a commentary on this memorial album that commerce and culture are two main themes that allow us to grasp the two hundred years history of intercourse between the United States and China. ${ }^{7}$ It is through bilateral trade that young Americans begin to contact and understand the Chinese nation. By sending missionaries, they begin to introduce American values and cultures to China with passion. It goes without saying that Samuel Wells Williams has an unshakable place in that album. During the first and second opium wars, it was with the efforts of those Americans, who came to China earlier than Anson Burlingame, and the values and the morals of young American nation which ultimately prevented the United States from doing as much harm to China as did the British.

Through his good deeds, Anson Burlingame raised the dialogue between the two nations to a spiritual level. The Burlingame Treaty provided a broad

6 Daily Evening Bulletin, Aug.29, 1872.

7 John Israel, “《共同走过的日子-美中交往两百年》A Journey Shared: The United States and China-Two Hundred Years of History," The Chinese Historical Review, 19:2, 163. 
platform for all-round intercourse between the two nations in the spiritual field and laid a solid foundation for the centuries-old Sino-American cooperation. As discussed in this work, it is on this basis that Goodnow putted forward his own unique views on China's constitutionalism. Dewey's philosophical thoughts have influenced a large number of Chinese modern thinkers, including Hu Shi. Even in the cold war period, countless Chinese, who were educated in the United States before 1949, silently prayed for the renewed cooperation between China and the United States. In fact, they are the successors of Anson Burlingame, the watchers of friendly intercourse between China and the United States, and the promoters of close cooperation between China and the United States. The good wills of Anson Burlingame's spirit is embodied and inherited in them.

As Akira Iriye commented in the preface of this work, Xu's monograph breaks through the category of traditional historical research, standing at the height of the community of human destiny, it expands the field of investigation from one country's history and one nation's history to the field of multicultural coexistence. It shows the progress and integration of human civilization and society by studying important historical figures and events. This kind of research thinking and its achievements inspire the younger generation of historical researchers, who are exerting a far-reaching and lasting influence not only in the field of historical research, but also in the international field of cooperation and multicultural integration. As far as I am concerned, this masterpiece has greatly benefited me and has become an important spiritual motive force guiding my future research.

Finally, I would like to conclude this review by quoting a statement by Gu Wei-jun, the Chinese minister dispatched to the United States shortly after the establishment of the Republic of China, the first republic in Asia. This message fully reflected China's new generation who were engaged in the development of Sino-Western intercourse initiated by Anson Burlingame, the first messenger of China and United States.

One of these facts is that the Chinese people are a progressive people. It was only fifty years ago, in 1868, that Anson Burlingame, in response to the welcome extended to him by the citizens of New York as the head of the first Chinese diplomatic mission sent abroad, announced that China was "ready to take upon her ancient civilization the graft of your civilization." Since that time progress in the modernization of China has been very rapid. ${ }^{8}$

8 Vi Kyuin Wellington Koo, "The New China and Her Relation to the World," Proceeding of the Academy of Political Science, vol.7, No.3 (1917): pp.1+3-9. 